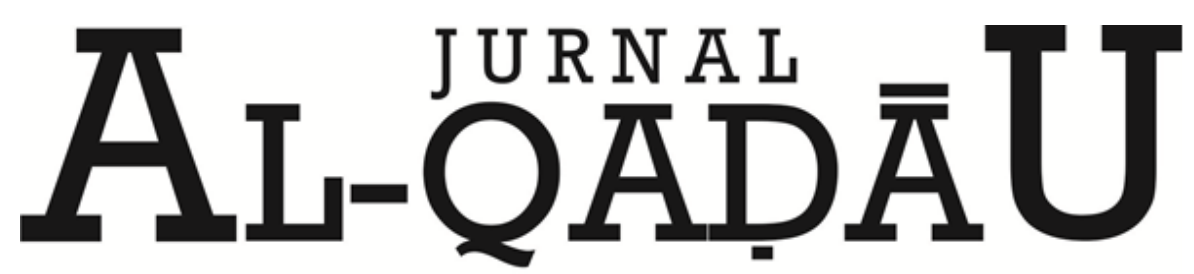

PERADILAN dan HUKUM KELUARGA ISLAM

\title{
Implementasi antara Legislatif dan Eksekutif dalam Pembentukan Peraturan Daerah yang Partisipatif
}

Implementation between Legislative and Executives in Establishing Participative Regional Regulations

Adriana Mustafa

Dosen Fakultas Syariah dan Hukum UIN Alauddin Makassar

Email: adriana.mustafagmail.com

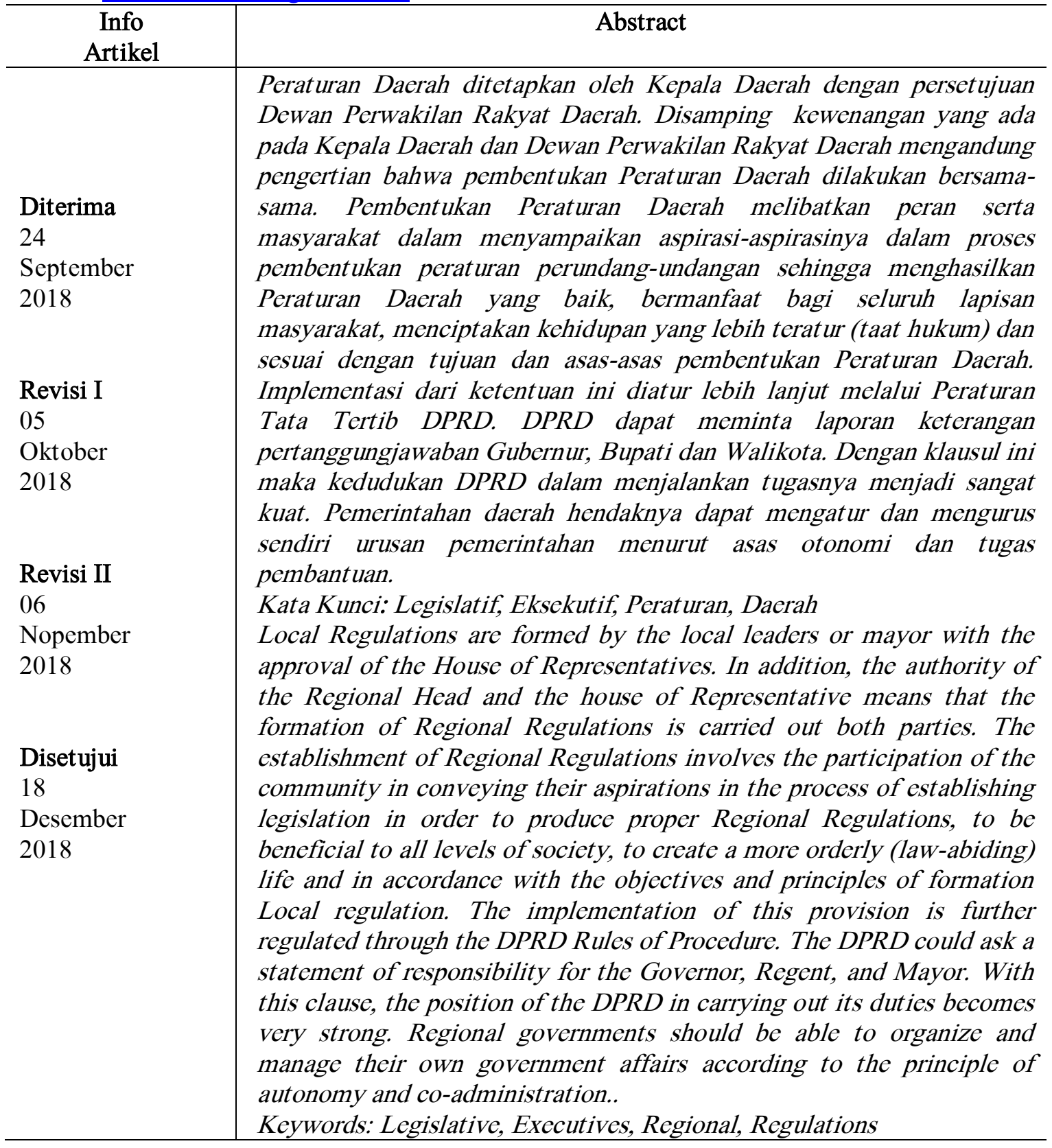




\section{A. PENDAHULUAN}

Undang-Undang Dasar Negara Republik Indonesia Tahun 1945 Pasal 1 ayat (3) menegaskan bahwa "Negara Indonesia adalah negara hukum".

Praktek penyelenggaraan negara dewasa ini, dikenal melalui 3 (tiga) lembaga hukum (peraturan perundang-undangan) yakni pembuat Undang-Undang (Legislatif), pelaksana Undang-Undang (Eksekutif) dan pengadilan terhadap Undang-Undang (Yudikatif). Undang-Undang Dasar Negara Republik Indonesia Tahun 1945 Pasal 20 ayat (1) menyebutkan bahwa : Dewan Perwakilan Rakyat memegang kekuasaan membentuk Undang-Undang. Selanjutnya ayat (2) menyebutkan bahwa : Setiap Rancangan Undang-Undang dibahas oleh Dewan Perwakilan Rakyat dan Presiden untuk mendapat persetujuan bersama. ${ }^{2}$.

Pada tingkat provinsi disebut Gubernur, sedangkan untuk kabupaten disebut Bupati dan untuk kota disebut Walikota. Setiap Kepala Daerah dibantu oleh satu orang Wakil Kepala Daerah. Untuk provinsi disebut Wakil Gubernur sedangkan untuk kabupaten disebut Wakil Bupati dan untuk kota disebut Wakil Walikota. Kepala Daerah dan Wakil Kepala Daerah dimaksud dipilih dalam satu pasangan secara langsung olehrakyat di daerah yang bersangkutan yang persyaratan dan tata caranya ditetapkan peraturan perundang-undangan.

DPRD mempunyai kedudukan sebagai badan legislatif daerah, seperti halnya di struktur pemerintah pusat. DPR memegang kekuasaan membentuk Undang-Undang. Kedudukan DPRD sebagai badan legislatif daerah, membawa akibat bahwa DPRD harus lebih banyak melakukan peran yang berkait dengan kewenangan dan kewajiban yang dibebankan oleh UU terhadap DPRD. Konsekuensi dari DPRD sebagai badan legislatif daerah, semua produk perundang-undangan daerah harus menggunakan dan bersumber dari DPRD. ${ }^{3}$

Rancangan Peraturan Daerah yang akan dibahas secara bersama dapat berasal dari pemerintah daerah maupun dari Dewan Perwakilan Rakyat Daerah. Jika Rancangan Peraturan Daerah yang berasal dari pemerintah daerah, dapat disampaikan melalui surat pengantar Gubernur/Bupati/Walikota kepada Dewan Perwakilan Rakyat Daerah dan jika Rancangan Peraturan Daerah yang berasal dari Dewan Perwakilan Rakyat Daerah dapat disampaikan melalui pimpinan Dewan Perwakilan Rakyat Daerah kepada badan pemerintah daerah (Gubernur/Walikota). Dengan memperhatikan uraian di atas, maka dapatlah ditarik rumusan masalah bagaimana hubungan Legislatif dengan Eksekutif dalam pembentukan Peraturan Daerah yang partisipatif dan Bagaimana proses pembentukan Peraturan Daerah antara Eksekutif dan Legislatif menurut Undang-Undang Nomor 32 Tahun 2004.

${ }^{1}$ UUD 1945 \& Perubahannya (Cet. IV; Jakarta: PT. Wahyu Media, 2017), h.7

${ }^{2}$ UUD 1945 \& Perubahannya, h.18

${ }^{3}$ Abdul Latief, Tinjauan Hukum Kekuasaan Eksekutif Daerah \& Lagislatif Daerah (Jakarta: Jurnal UNHAS (Meristorasi), 2003), h.281 
Adriana Mustafa

\section{B. METODE PENELITIAN}

Lokasi yang dijadikan tempat untuk mengkaji berbagai fenomena hukum yaitu fokus pada kantor Dewan Perwakilan Rakyat daerah Kabupaten Soppeng, dan Pemerintah Daerah Kabupaten Soppeng. Pemilihan lokasi tersebut didasarkan atas pertimbangan bahwa kedua instansi tersebut merupakan lembaga yang memiliki kewenangan untuk membentuk dan melahirkan Peraturan Daerah yang partisipatif dan berkualitas.

Jenis dan sumber data yang diperlukan dalam penelitian ini adalah data primer (data utama) dan data sekunder (data pelengkap). Kedua jenis data tersebut didapatkan melalui : Penelitian lapangan (data primer), yakni Buku, makalah, artikel, jurnal, kamus, majalah, koran, dll (data sekunder).

Teknik pengumpulan data terdiri dari penelitian lapangan yaitu pengumpulan data dengan jalan wawancara (interview) guna mendapatkan data yang lebih mendalam tentang obyek penelitian. Dan penelitian pustaka yaitu pengumpulan data dengan jalan membaca dan menganalisis dokumen-dokumen yang kemudian disesuaikan dengan obyek penelitian.

\section{PEMBAHASAN}

\section{Pengertian Kepala Daerah dan Dewan Perwakilan Rakyat Daerah (DPRD)} Kepala Daerah

Pada daerah ditentukan adanya Lembaga Eksekutif Daerah dan Lembaga Legislatif Daerah yang sederajat dan saling mengontrol satu sama lain sesuai dengan prinsip checks and balances power. Di daerah provinsi, pihak pemerintah dipimpin oleh Gubernur yang mempunyai kedudukan sebagai Kepala Daerah dan sekaligus sebagai Kepala Wilayah yang mewakili Pemerintah Pusat. Sedangkan di Daerah Kabupaten, pihak pemerintah dipimpin oleh Bupati dan di daerah Kota dipimpin oleh Walikota yang masing-masing berkedudukan sebagai Kepala Daerah Otonom.

\section{Dewan Perwakilan Rakyat Daerah (DPRD)}

Dewan Perwakilan Rakyat Daerah dibentuk baik di daerah provinsi maupun di daerah Kabupaten dan Kota. Pada umumnya, dewan perwakilan ini disebut sebagai lembaga yang menjalankan kekuasaan legislatif, dan karena itu biasa disebut dengan lembaga legislatif daerah.

Jimly Asshiddiqie menulis bahwa fungsi utama DPRD adalah untuk mengontrol jalannya pemerintahan di daerah, sedangkan berkenaan dengan fungsi legislatif, posisi DPRD bukanlah aktor yang dominan. Pemegang kekuasaan yang dominan di bidang legislatif itu tetap Gubernur atau Bupati/Walikota. Bahkan dalam Undang-Undang Nomor 32 Tahun 2004, Gubernur dan Bupati/Walikota ("diwajibkan") mengajukan rancangan Peraturan Daerah dengan persetujuan DPRD. Artinya, DPRD itu hanya bertindak sebagai lembaga pengendali atau pengontrol yang dapat menyetujui, menolak ataupun menyetujui dengan perubahan-perubahan, dan sekali-sekali dapat mengajukan usul inisiatif sendiri mengajukan rancangan Peraturan Daerah. ${ }^{4}$ 2005), h.297

${ }^{4}$ Jimly Asshiddiqie, Hukum Tata Negara \& Pilar-Pilar Demokrasi (Jakarta: Konstitusi Press, 


\section{Hubungan Eksekutif dan Legislatif}

Menurut Siswanto Sunarso, Legislatif sebagai pemegang kekuasaan policy making (taakstelling), sedangkan eksekutif sebagai pelaksana kekuasaan policy executing (taak verzenlijking). Badan legislatif membuat aturan perundang- undangan, sedangkan eksekutif yang melaksanakan aturan perundang-undangan.Hubungan antara badan legislatif dan badan eksekutif tersebut menimbulkan suatu sistem di dalam hukum tata negara, disebut sebagai sistem pemerintahan. ${ }^{5}$

\section{Pengertian Peraturan Daerah}

Undang-Undang Nomor 10 Tahun 2004 Pasal 1 Ayat (7) menyebutkan bahwa Peraturan Daerah adalah peraturan perundang-undangan yang dibentuk oleh Dewan Perwakilan Rakyat Daerah dengan persetujuan bersama kepala daerah. ${ }^{6}$ Selanjutnya dalam Pasal 12 dikatakan bahwa, Materi muatan Peraturan Daerah adalah seluruh materi muatan dalam rangka penyelenggaraan otonomi daerah dan tugas pembantuan, dan menampung kondisi khusus daerah serta penjabaran lebih lanjut Peraturan Perundang-undangan yang lebih tinggi. ${ }^{7}$

\section{Tata Cara Pembentukan Peraturan Daerah}

Peraturan Daerah merupakan peraturan perundang-undangan. Sebagaimana telah diketahui bahwa Peraturan Daerah itu semacam Undang-Undang. Karena itu kewenangan pembentuknya mengikuti kewenangan pembentukan Undang-Undang. Peraturan Daerah dibentuk berdasarkan pada asas pembentukan peraturan perundangundangan yang meliputi : Kejelasan tujuan; kelembagaan atau organ pembentuk yang tepat; kesesuaian antara jenis dan materi muatan; dapat dilaksanakan; kedayagunaan dan kehasilgunaan; kejelasan rumusan; dan keterbukaan. ${ }^{8}$

Peraturan Daerah ditetapkan oleh Kepala Daerah dengan persetujuan Dewan Perwakilan Rakyat Daerah. Telah dikemukakan pula, dalam Penjelasan Umum Undang-Undang Nomor 32 Tahun 2004 disebutkan bahwa kewenangan yang ada pada Kepala Daerah dan Dewan Perwakilan Rakyat Daerah mengandung pengertian bahwa pembentukan Peraturan Daerah dilakukan bersama-sama. ${ }^{9}$

Hubungan Legislatif dan Eksekutif terhadap Pembentukan Peraturan Daerah Menurut Undang-Undang Nomor 32 Tahun 2004

Undang-Undang Dasar Negara Republik Indonesia Tahun 1945 Pasal 20 Ayat (2) menegaskan bahwa :

Setiap Rancangan Undang-Undang dibahas oleh Dewan Perwakilan Rakyat dan Prsiden untuk mendapat persetujuan Bersama. ${ }^{10}$

${ }^{5}$ Siswanto Sunarso, Hubungan Kemitraan Badan Eksekutif \& Legislatif di Daerah (Bandung: Mandar Maju, 2005), h.41

${ }^{6}$ Undang-Undang RI No. 10 Tahun 2004, tentang Pembentukan Peraturan Perundang-undangan (Cet.V; Jakarta: Sinar Grafika, 2010), h.3

${ }^{7}$ Undang-Undang RI No. 10 Tahun 2004, h.7

${ }^{8}$ Hamidi Jazim, Pembentukan Peraturan Daerah Partisipatif(Malang:Prestasi Pustaka, 2008), h.

h. 183

\footnotetext{
${ }^{9}$ Undang-Undang No.32 Tahun 2004 tentang Pemerintahan Daerah (Bandung: Fermana, 2004),
}

${ }^{10}$ UUD 1945 \& Perubahannya, h.18 
Selanjutnya ditentukan pula dalam Undang-Undang Nomor 32 Tahun 2004 Pasal 136 Ayat (1) bahwa :

Peraturan Daerah ditetapkan oleh Kepala Daerah setelah mendapat persetujuan bersama dengan DPRD. ${ }^{11}$

Rumusan tersebut menandakan bahwa Dewan Perwakilan Rakyat sebagai penjelmaan dari Legislatif Institute dan Presiden sebagai Eksecutive Institute memiliki hubungan yang sangat erat dalam hal pembahasan Rancangan Undang-Undang. Begitupun juga dengan lembaga Legislatif Daerah dan Eksekutif Daerah dalam hal pembentukan Peraturan Daerah.

Undang-Undang Nomor 32 Tahun 2004 yang disahkan oleh Presiden 15 Oktober 2004 adalah suatu produk reformasi perundang-undangan kedua setelah Undang-Undang Nomor 22 Tahun 1999 di bidang Pemerintahan Daerah. Gagasan tentang lahirnya Undang-Undang "Pemerintahan Daerah" telah mencerminkan perubahan politik hukum pemerintahan dari pemerintahan yang sentralistik mengarah pada pemerintahan yang desentralistik. Arah pemerintahan yang desentralistik itu tidak terlepas dari latar belakang timbulnya gerakan lokal yang menunt ut terjadinya proses demokratisasi dan keterbelakangan struktural di daerah. Pemerintahan Orde Baru yang gagal memeratakan hasil pembangunan di Indonesia nampaknya juga menjadi pemicu terhadap pembaruan sistem pembagian sumber kekayaan alam.

Salah satu hak yang baru buat DPRD adalah "Hak meminta pertanggungjawaban Gubernur, Bupati dan Walikota". Hak ini merupakan hal yang sangat maju terutama dalam mengawal proses demokrasi di Negara ini sebagaimana yang ada dalam Undang-Undang Nomor 32 Tahun 2004, yang sebelumnya dapat dikatakan sama sekali tidak dikenal oleh pemerintahan daerah yang pernah berlaku, apakah Undang-Undang Nomor 5 Tahun 1974, Undang-Undang Nomor 18 Tahun 1965 dan bahkan Undang-Undang Nomor 1 Tahun 1975 yang sangat dikenal memberikan otonomi yang seluas-luasnya kepada Pemerintah Daerah.

Undang-Undang Nomor 32 Tahun 2004 Pasal 43 Ayat (1) dan secara terperinci menyatakan hak-hak DPRD sebagai berikut :
a. Interpelasi;
b. Angket;
c. Menyatakan pendapat

Dan selanjutnya pada Pasal 44 Ayat (1) :
a. Mengajukan rancangan Perda;
b. Mengajukan pertanyaan;
c. Menyampaikan usul dan pendapat;
d. Memilih dan dipilih;
e. Membela diri;
f. Imunitas;
g. Protokoler; dan

${ }^{11}$ Undang-Undang No. 32 Tahun 2004, h. 116 
h. Keuangan dan administratif

Kalau kita mengkaji lebih lanjut ketentuan Undang-Undang Nomor 32 Tahun 2004, maka menurut M. Ryaas Rasyid, kita akan menemukan sejumlah hal yang sangat menonjol yang menyangkut kedudukan dan kewenangan DPRD dan hal itu jelas merupakan sebuah inovasi baru dari Undang-Undang tersebut antara lain; Pertama, fraksi bukan lagi merupaan alat kelengkapan DPRD, Pasal 46 Ayat (1), yang menjadi alat kelengkapan DPRD adalah Pimpinan, Komisi-komisi, Panitia Musyawarah, Panitia Anggaran, Badan Kehormatan dan alat kelengkapan lainnya. Implikasi dari kenyataan ini adalah beban dari Pemerintah Daerah dapat berkurang, paling tidak daerah tidak perlu lagi menyediakan sarana, fasilitas, dan gaji yang secara khusus disediakan buat Ketua dan Sekretaris Fraksi. Memang sebenarnya dimanapun, Fraksi bukan merupakan alat kelengkapan Dewan, karena Fraksi lebih merupakan kepanjangan tangan dari partai masing-masing. Fraksi diperlukan oleh partai agar anggota dewan yang berasal dari partai mempunyai tingkat kedisiplinan yang tinggi dalam menjalankan kebijaksanaan partai di lembaga perwakilan rakyat, dan disamping itu agar anggota fraksi tersebut menempuh langkah yang berbeda sama sekali dengan kebijaksanaan partai.

Kedua, Contemp of Parliament. Untuk pertama kalinya DPRD dapat memaksa seorang pejabat negara, atau pejabat pemerintah, atau bahkan warga negara kebanyakan untuk memberikan keterangan dihadapan DPRD, kalau memang lembaga tersebut memerlukan keterangan atau informasi dari pejabat ataupun warga masyarakat. Kalau sampai seorang pejabat ataupun seorang warga negara menolak untuk memberikan keterangan, sementara keterangan tersebut warga negara menolak untuk memberian keterangan, sementara keterangan tersebut sangat diperlukan oleh DPRD dalam rangka pelaksanaan tugasnya, maka pejabat atau warga negara tersebut dikenakan ancaman yang disebut Contemp of Parliament. Dan kalau hal itu sampai terjadi maka yang bersangkutan akan dikenakan sanksi hukum. ${ }^{12}$

Pasal 43 Undang-Undang Nomor 32 Tahun 2004 mengat ur tentang masalah itu. Pasal tersebut menyatakan bahwa "ayat (4) Dalam melaksanakan tugasnya, panitia angket, dapat memanggil mendengar dan memeriksa seseorang yang dianggap mengetahui atau patut mengetahui masalah yang sedang diselidiki serta untuk meminta menunjukkan surat atau dokumen yang berkaitan dengan hal yang sedang diselidiki". Ayat (5) "setiap orang yang dipanggil, didengar, dan diperiksa wajib memenuhi panggilan panitia angket kecuali ada alasan yang sah menurut peraturanperaturan perundang-undangan". Selanjutnya di ayat (6) dinyatakan pula bahwa "dalam hal telah dipanggil dengan patut secara berturut-turut tidak memenuhi panggilan panitia angket dapat memanggil secara paksa dengan bantuan Kepolisian Negara Republik Indonesia sesuai dengan peraturan perundang-undangan". ${ }^{13}$ Sementara itu bagaimana implementasi dari ketentuan ini akan diatur lebih lanjut melalui Peraturan Tata Tertib DPRD. 2002), h.194

${ }^{12}$ M. Ryaas Rasyid, Otonomi Daerah Dalam Negara Kesatuan (Yogyakarta: Pustaka Pelajar,

${ }^{13}$ UU No.32 Tahun 2004, h.46 
Ketiga, DPRD dapat meminta laporan keterangan pertanggungjawaban Gubernur, Bupati dan Walikota. Hal ini juga merupakan sesuatu yang dapat dikatakan baru dan bagian dari misi reformasi dari Undang-Undang ini. Dapat pula dikatakan bahwa dengan klausul ini maka kedudukan DPRD menjadi sangat kuat. Dalam menjalankan tugasnya Kepala Daerah wajib menyampaikan laporan atas kegiatan penyelenggaraan pemerintahan di wilayahnya kepada Presiden melalui Menteri Dalam Negeri. Untuk Bupati dan Walikota, laporan tersebut tembusannya juga wajib disampaikan kepada Gubernur yang menjadi Kepala Daerah Provinsi. Laporan tersebut wajib disampaikan setahun sekali kepada Presiden (Pasal 27 ayat (3) Undang-Undang Nomor 32 Tahun 2004).

Keempat, DPRD dapat mengusulkan pengangkatan dan pemberhentian Kepala Daerah/Wakil Kepala Daerah kepada Presiden. (Pasal 42 Ayat (1) huruf d UndangUndang Nomor 32 Tahun 2004). Bagaimana kalau laporan pertanggungjawaban yang disampaikan oleh Kepala Daerah ditolak oleh DPRD?. Kalau Kepala Daerah harus melengkapi dan/atau menyempurnakannya dalam jangka waktu tertentu. Untuk lebih jelasnya dapat dilihat dalam Undang-Undang Nomor 22 Tahun 2003 Pasal 78 Ayat (1) huruf d. ${ }^{14}$

Sekalipun implikasinya akan sangat luas, tetapi klausul ini jelas sangat memperkuat kedudukan, fungsi dan kewenangan DPRD, apalagi karena DPRD diberi hak untuk memberikan "semacam mosi tidak percaya" kalau sampai dua kali menolak pertanggungjawaban Kepala Daerah. Namun, agar DPRD tidak akan dengan semenamena menyalahgunakan hak dan wewenang yang diberikan oleh Undang-Undang, maka Presiden yang harus memberikan kata akhir tentang penolakan pertanggungjawaban dari Kepala Daerah. Jadi, Presiden kedudukannya sebagai penengah atau wasit jika terjadi sengketa antara Lembaga Legislatif dan Lembaga Eksekutif di daerah.

\section{Tugas dan Kekuasaan Eksekutif}

Pemerintahan adalah kegiatan penyelenggaraan guna memberikan pelayanan dan perlindungan bagi segenap warga masyarakat, melakukan pengaturan, memobilisasi semua sumber daya yang diperlukan, serta membina hubungan baik dengan negara lain. Di tingkat lokal tentu saja membina hubungan dengan pemerintahan nasional dan pemerintahan daerah yang lainnya. Itulah yang dimaksud dengan pemerintahan.

Pemerintahan dalam arti yang luas menyangkut kekuasaan dan kewenangan dalam bidang legislatif, eksekutif dan yudikatif. Eksekutif hanyalah kegiatan pemerintahan dalam arti yang sempit. Secara tradisional, dipahami bahwa ada pembagian kekuasaan yang sangat tegas diantara ketiga lembaga tersebut. Legislatif melakukan pengaturan, membuat kebijaksanaan. Sementara pihak eksekutif melaksanakan atau mengimplementasikan apa yang diatur atau diputuskan oleh pihak legislatif, dan kekuasaan yudikatif memberikan sanksi atas penyimpangan atau pelanggaran yang dilakukan oleh kekuasaan eksekutif terhadap apa yang sudah diputuskan oleh kekuasaan legislatif.

\footnotetext{
${ }^{14}$ M.Ryaas Rasyid, Otonomi Daerah Dalam Negara Kesatuan, h.196
} 
Pentingnya Naskah Akademik dalam penyusunan sebuah peraturan perundangundangan juga dikemukakan oleh Prof. Abdul Gani Abdullah (Ketua Badan Pembina Hukum Nasional/BPHN), beliau mengatakan :

"Dalam Undang-Undang Nomor 10 Tahun 2004 tidak disebutkan secara tegas bahwa setiap Rancangan Undang-Undang harus dibuat naskah akademisnya. Tetapi naskah akademis diperlukan untuk memperjelas posisi Rancangan Undang-Undang itu dalam sistem hukum nasional maupun sesuai tidaknya dengan kehidupan masyarakat. Sekalipun demikian ada juga yang tidak menggunakan naskah akademis terlebih dahulu. Seperti yang dibuat oleh inisiatif Dewan Perwakilan Rakyat, itu kelihatannya tidak perlu naskah akademis. Tetapi sekarang ini mereka perlu naskah akademis. Sehingga Baleg Dewan Perwakilan Rakyat mengharapkan ada kerjasama dengan BPHN. Sudah ada pembicaraan mengenai itu dan mengharap pentingnya suatu naskah akademis sekalipun ada Undang-Undang yang tidak mempunyai naskah akademis. Akhirnya punya persoalan seperti judicial review. Naskah akademis disini dibutuhkan untuk mem-backup keterangan pemerintah". ${ }^{15}$

Urgensi dari Naskah Akademik dalam proses pembentukan Peraturan Daerah antara lain Naskah Akademik merupakan media nyata bagi peran serta masyarakat dalam proses pembentukan Peraturan Daerah, bahkan inisiatif penyusunan Naskah Akademik dapat berasal dari masyarakat.

Hal ini merupakan sebuah keuntungan tersendiri, dengan terlibatnya masyarakat dalam proses pembentukan Peraturan Daerah, maka aspirasi-aspirasi masyarakat akan lebih terakomodasi. Peran serta masyarakat ini juga sesuai dengan perumusan Pasal 53 Undang-Undang Nomor 10 Tahun 2004 jo. Pasal 139 Ayat (1) Undang-Undang Nomor 32 Tahun 2004.

Peraturan dianggap sebagai suatu aturan yang efektif apabila tidak melupakan sejauh mana tingkat kebutuhan masyarakat, keinginan masyarakat, interaksi masyarakat terhadap peraturan tersebut. Ini menjadi porsi dari kajian sosiologis untuk menjelaskannya. Kajian ini menguraikan realitas masyarakat yang meliputi kebutuhan hukum masyarakat, kondisi masyarakat dan nilai-nilai yang hidup dan berkembang (rasa keadilan).

Digunakannya Naskah Akademik dalam proses pembentukan peraturan perundang-undangan, akan tercipta sebuah peraturan perundang-undangan yang berbasis penelitian (ilmiah), sehingga dihasilkan Peraturan Daerah yang baik, bermanfaat bagi seluruh lapisan masyarakat, menciptakan kehidupan yang lebih teratur (taat hukum) dan sesuai dengan tujuan dan asas-asas pembentukan Peraturan Daerah.

Partisipasi masyarakat dalam proses pembuatan Naskah Akademik daerah, tidak hanya sekedar pada proses pembentukan Naskah Akademik saja melainkan terus berlanjut pada proses perencanaan, pembahasan, pengesahan dan pemberlakuan Peraturan Daerah, bahkan partisipasi masyarakat tetap diperlukan sampai pada tahap pengevaluasian setelah berlakunya Peraturan Daerah. Hal ini berkesesuaian dengan pendapat tentang tahap-tahap partisipasi masyarakat yang berpendapat bahwa partisipasi masyarakat dapat terjadi pada empat jenjang :

${ }^{15}$ Siswanto Sunarso, Pedoman Penyusunan Naskah Akademik Peraturan Daerah Partisipasi, (Jakarta: Total Media, 2006), h.92 
a. Partisipasi dalam proses pembuatan keputusan;

b. Partisipasi dalam pelaksanaan;

c. Partisipasi dalam pemanfaatan hasil;

d. Partisipasi dalam evaluasi.

Setelah mengadakan komunikasi internal, atas inisiatif dari penyusun Naskah Akademik atau atas inisiatif bersama, diadakan forum komunikasi yang lebih besar dengan semua pihak yang terkait, misalnya mengadakan sebuh seminar, lokakarya, diskusi publik atau forum Group Discussion (FGD) yang menghadirkan semua pihak yang terkait dan membahas permasalahan yang ada.

Tujuan diadakan komunikasi bersama ini adalah untuk menyamakan visi dan persepsi dari masing-masing pihak mengenai permasalahan yang dibahas, sehingga pada akhirnya dicapai pandangan yang sama dari masing-masing pihak bahwasannya permasalahan yang ada pada masyarakat ini perlu dibuat Perdanya dengan Naskah Akademik sebagai bagian dari proses pembentukan Perda.

Wadah forum komunikasi ini, penyusun Naskah Akademik mempunyai peranan yang sangat penting, penyusun Naskah Akademik harus mampu menjadi fasilitator sekaligus mediator dalam menjembatani perbedaan visi dan persepsi yang mungkin muncul dalam forum tersebut sehingga tercipta kesamaan visi dan persepsi mengenai permasalahan yang sedang dibahas.

\section{Pembentukan Peraturan Daerah yang partisipatif di Kabupaten Soppeng}

Undang-undang Dasar Negara Repoblik Indonesia Tahun 1945 Pasal 18 ayat (6) menegaskan bahwa:

Pemerintah daerah berhak menetapkan peraturan daerah dan peraturanperaturan lain untuk melaksanakan otonomi dan tugas pembantuan

Kemudian dalam ayat (7) menentukan :

Susunan dan tata cara penyelenggaraan pemerintah daerah diatur dalam undang-undang

Pemerintahan daerah dimaksud dapat mengatur dan mengurus sendiri urusan pemerintahan menurut asas otonomi dan tugas pembantuan. Pemerintahan daerah menjalankan otonomi seluas-luasnya, kecuali urusan pemerintahan yang menjadi urusan pemerintah, dengan tujuan meningkatkan kesejahteraan masyarakat, pelayanan umum, dan daya saing daerah. ${ }^{16}$

Pasal 3 ayat (1) dan ayat (2) Undang-undang Nomor 32 Tahun 2004, dinyatakan bahwa pemerintahan daerah sebagaimana dimaksud di atas adalah (a) pemerintahan daerah provinsi yang terdiri atas pemerintah daerah provinsi dan DPRD provinsi, dan (b) pemerintahan daerah kabupaten/kota dan DPRD kabupaten /kota. Sedangkan yang dimaksud dengan Pemerintah Daerah adalah terdiri dari atas kepala daerah dan perangkat daerah.

Mengenai Peraturan Daerah ini, sejalan dengan agenda desentralisasi dan atonomi daerah yang makin luas, sangat perlu untuk dilakukan kedudukannya sehingga dapat bersifat mandiri tanpa ada campur tangan dari pihak manapun. Dari segi

${ }^{16}$ UU No.32 Tahun 2004, h.12-13 
pembentukannya, sudah semestinya kedudukan Peraturan Daerah baik tingkat Provinsi maupun tingkat kabupaten atau kota, dapat dilihat setara dengan Undang-undang dalam arti sama-sama merupakan produk hukum Lembaga Legislatif.

Namun demikian, dari segi isinya sudah seharusnya, kedudukan peraturan yang mengatur materi dalam ruang daerah berlaku yang lebih sempit dianggap mempunyai kedudukan yang lebih rendah dibanding peraturan perundang-undangan yang lebih tinggi dengan ruang lingkup wilayah berlaku lebih luas. Dengan demikian undangundang lebih tinggi kedudukannya dari pada Peraturan Daerah Provinsi, dan Peraturan Daerah Kabupaten atau kota. Karena itu, sesuai prinsip hirarki peraturan perundangundangan, peraturan yang lebih rendah itu tidak boleh bertentangan dengan peraturan yang derajatnya lebih tinggi.

Konsekuensi dipertegaskan prinsip pemisahan kekuasaan eksekutif, legislatif dan yudikatif dalam naskah Perubahan Pertama Undang-undang Dasar 1945 maka produk legislatif daerah ini dapat saja bertentangan dengan produk eksekutif tingkat pusat. Misalnya, apabilah suatu meteri Peraturan Daerah tingkat provinsi ataupun Peraturan Daerah tingkat kabupaten/kota yang telah ditetapkan secara sah ternyata bertentangan isinya dengan materi Peraturan Daerah di tingkat Pusat maka pengadilan haruslah menentukan bahwa Peraturan Daerah itulah yang berlaku sepanjang untuk daerahnya.

Peraturan Menteri dimaksudkan untuk berlaku umum di seluruh Indonesia. Oleh karena itu, ketentuan yang mengatur bahwa Peraturan Daerah harus disahkan terlebih dahulu oleh Pemerintah Pusat, dalam hal ini oleh Menteri Dalam Negeri, harus dinyatakan tidak berlaku lagi.

Menurut salah seorang anggota Komisi I DPRD Kabupaten Soppeng yang membidangi masalah Pemerintahan, Komunikasi, Tenaga Kerja dan Transmigrasi, mengatakan bahwa : dalam proses pembentukan Perda di Kabupaten Soppeng sama sekali tidak ada hambatan karena berjalan sesuai dengan mekanisme yang ada hanya saja yang menjadi masalah adalah implementasi atau penerapan Perda di masyarakat. Menurutnya, ada beberapa Perda yang dberlakukan padahal belum tersosialisasi dengan baik sehingga dipertanyakan kembali oleh sebagian masyarakat.

Senada dengan hal ini, salah seorang anggota Komisi II DPRD Kabupaten Soppeng yang membidangi masalah Perekonomian, Keuangan dan Kesejahteraan Sosial, mengatakan bahwa hambatan-hambatan seperti ini tidak akan terjadi seandainya dari awal Pemerintah Daerah Kabupaten Soppeng melakukan sosialisasi yang baik, menurut Peraturan Perundang-undangan.

Adapun sebab-sebab sehingga Perda yang dibentuk tidak dapat dilaksanakan secara maksimal yaitu :

1. Kurangnya sosialisasi sebelumnya tentang muatan materi Rancangan Peraturan Daerah sebelum dibahas oleh Dewan Perwakilan Rakyat Daerah bersama Pemerintah Daerah Kabupaten Soppeng;

2. Tidak ada peran serta partisipasi masyarakat dalam hal mengkaji muatan materi Rancangan Peraturan Daerah;

3. Pelaksanaan Perda yang terbentur oleh kebutuhan masyarakat, karena dalam pembentukannya tidak didasarkan atas kebutuhan masyarakat. Oleh karena itu dalam pembentukan Perda, sangat penting adanya Naskah Akademik untuk lahirnya suatu Perda yang partisipatif. 


\section{PENUTUP}

\section{Kesimpulan}

Pemerintah mempunyai tanggungjawab atas kesejahteraan rakyat. Peningkatan kesejahteraan masyarakat dapat diukur dari keberhasilan daerah dalam mengelola kesehatan masyarakat, pendidikan dan kebudayaan, pertanian, perhubungan, industri, penanaman modal, lingkungan hidup, pertahanan, koperasi, tenaga kerja dan perumahan rakyat. Keberhasilan itu sangat dipengaruhi oleh kinerja pemerintah.

Dewan Perakilan Rakyat Daerah (DPRD) mempunyai kewajiban atas kesejahteraan rakyat daerah. Kewajiban itu dapat dilakukan dengan meningkatkan sumber penerimaan daerah dari sektor pajak karena daerah dan retribusi daerah melalui Peraturan Daerah. Kontribusi DPRD dalam upaya peningkatan kesejahteraan.

\section{Implikasi}

Dewan Perwakilan Rakyat Daerah (DPRD), khususnya di Kabupaten Soppeng harusnya lebih mengutamakan kepentingan rakyat melalui jaminan kesejahteraan sosial, pendidikan, pertanian, kesehatan dan lain-lain. Sebelum pembahasan Peraturan Daerah, DPRD harusnya melakukan sosialisasi terlebih dahulu dan meminta tanggapan masyarakat agar dalam pelaksanaan Peraturan Daerah tersebut dapat berjalan secara optimal.

\section{DAFTAR PUSTAKA}

Asshidiqie, Jimly.Hukum Tata Negara dan Pilar-Pilar Demokrasi. Jakarta: Konstitusi Press, 2005.

---------, Pokok-Pokok Hukum Tata Negara Indonesia Pasca Reformasi, Kelompok Jakarta: Gramedia, 2007.

Harry, Alexander. Panduan Perancangan Peraturan Daerah di Indonesia. Jakarta: XS YS Solusiando, 2004.

Jazim, Hamidi. Pembentukan Perda Partisipatif. Malang: Prestasi Pustaka, 2008.

Latief, Abdul. Hukum dan Peraturan Kebijaksanaan (Beleidsregel) Pada Pemerintahan Daerah. Jogyakarta: UII Press, 2005.

. Tinjauan Hukum Kekuasaan Eksekutif Daerah dan Legislatif Daerah, Jurnal Makassar: UNHAS (Meristokrasi) 2003.

Manan, Bagir. Perkembangan UUD 1945. Jogyakarta: FH-UII Press, 2004.

. Menyongsong Fajar Otonomi Daerah. Jogyakarta: Pusat Studi FH-UII, 2004.

Pedoman Resmi UUD 1945 \& Perubahannya, Cet. IV; Jakarta: Wahyu Media, 2017.

Rasyid, M. Ryas. Otonomi Daerah Dalam Negara Kesatuan, Yogyakarta: Pustaka Pelajar bekerjasama dengan Pusat Pengkajian Etika Politik dan Pemerintahan, 2002.

Siswanto Sunarso, Hubungan Kemitraan Badan Eksekutif dan Legislatif di Daerah, Bandung: Mandar Maju, 2005.

----------, Pedoman Penyusunan Naskah Akademik Peraturan Daerah Partisipasi, Jakarta: Total Media, 2006.

Soenobo Wirjosoegito, Proses dan Perencanaan Peraturan Perundangan, Jakarta: Ghalia Indonesia, 2004. 
Implementasi antara Legislatif dan Eksekutif dalam

Pembentukan Kepala Daerah yang Partisipatif

Adriana Mustafa

Sony Maulana, 5 September 2005. Perencanaan Peraturan Daerah Sebagai Wujud Kontribusi Keikutsertaan Pemerintah Daerah Dalam Perubahan Sosial Yang Demokratis di Daerah, Makalah disampaikan pada Bimbingan Teknis Harmonisasi Peraturan Daerah (Perda) Wilayah Perbatasan Dalam Perspektif Hak Asasi Manusia, Samarinda.

Undang-Undang Otonomi Daerah No. 32 Tahun 2004 Tentang Pemerintahan Daerah, Fermana, Bandung.

Undang-Undang RI No. 10 Tahun 2004 Tentang Pembentukan Peraturan Perundangundangan, Cet. V; Jakarta: Sinar Grafika, t.thn. 